\title{
Психологические особенности развития представлений о супружеской ревности у студентов вуза
}

В статье актуализируется проблема исследования психологии семьи и супружеской ревности. Приведены результаты эмпирического исследования психологических особенностей развития представлений о супружеской ревности устудентов вуза. По состоянию сформированности представлений о супружеской ревности студенты вуза выделены три группы: студенты со сформированными, диффузными и иллюзорными представлениями о ревности

Ключевые слова: семья, супружеская ревность, представления осупружеской ресности.

Психология семьи является одной из значимых предметных областей изучения личности и субъекта деятельности. Личность формируется и развивается в пространстве семьи, в связи с чем, проблема внутрисемейного взаимодействия трансформируется в психолого-педагогический феномен, потребность в изучении которого проявляется не только в социальной психологии, в психологии личности, но и в педагогической психологии.

Практика показывает, что внутрисемейные отношения реализуются в разных формах, в их числе - на первый взгляд отрицательные проявления ревности супругов. Однако ревность как объект психологического исследования может служить источником выявления не только негативистских тенденций во внутрисемейных отношениях, но и источником формирования положительного опыта у будущих супругов. Проблема представлений о ревности как детерминанте супружеских отношений находится на стыке нескольких направлений исследовательских изысканий психологической науки.

Супружеские отношения подверглись в последние годы достаточно пристальной научной разработке. К настоящему времени изучены вопросы предбрачных отношений (Бурлачук Л.Ф., Коростылева Л.А., Шнейдер Л.Б., Сатир В. и др.), обозначены факторы (Эйдемиллер Э.Г., Юстицкис В.В., Юркович Н.А., Файнбург 3.) и механизмы (Голод И.С., Обозов Н.Н., Харчев А.Г., Сатир В., Уайл Г.) построения супружества, выделены разнообразные типы функционирования супружеских отношений (Андрух Г.П., Кратохвил С., Кришталь В.В., Сейгер Л., Шнейдер Л.Б.), установлены психологические причины их нарушения (Обозов Н.Н., Обозова А.Н.) и т.д. В проблемном поле психологии супружества обозначены также некоторые подходы к рассмотрению супружеской ревности (Васильева О.С., Куттер П., Линчевский Э.Э., Терентьев Е.И.). Вместе с тем, остаются невыясненным то, каковы психологические предпосылки функционирования ревности в супружеских отношениях. В частности, остается не ясной роль представлений о ревности в возникновении соответствующего феномена в супружеских отношениях. 
С другой стороны, в работах современных авторов (Гудова Н.В., Жубаркин С.В., Левченко А.В., Мацук М.А.) раскрыта роль психологических представлений в построении жизнедеятельности человека. В ряде исследований изучены особенности представлений о некоторых аспектах семейных и супружеских отношений. Так, А.М. Прихожан изучены представления подростков и юношей о своей будущей семейной жизни. Н.Г. Аристовой показана значимость представлений молодежи добрачного возраста о сексуальных отношениях и их последствиях. Л.С. Алексеевой вскрыта роль представлений о партнере в развитии отношений супругов. В этом контексте интерес вызывает изучение особенностей представлений о ревности как детерминанте супружеских отношений. Исходя из этого, мы обозначили цель нашего исследования - изучить психологические особенности представлений студентов о супружеской ревности. В исследовании приняли участие студенты ЮФУ общей численностью 250 человек. Основная гипотеза исследования: представления студентов о супружеской ревности выступают субъективной формой выражения их информированности о различных аспектах построения супружеских отношений.

Для проведения исследования были использованы следующие тестовые методики: личностный опросник В.М. Мельникова и Л.Т. Ямпольского, методика ценностных ориентаций М. Рокича, опросник базовых культурных ценностей С. Шварца, шкала-самооценка реактивной и личностной тревожности Ч.Д. Спилбергера и Ю.Л. Ханина.

В нашем исследовании были реализованы констатирующий и формирующий этапы эксперимента.

Констатирующий этап эксперимента в соответствии с поставленными эмпирическими задачами был направлен на фиксацию текущих особенностей представлений студентов о супружеской ревности и особенностей влияния на их характеристики ряда субъективных и объективных факторов. В рамках данного этапа эксперимента изначально выявлялось содержание и структура представлений студентов о супружеской ревности. Далее выявленные особенности представлений сопоставлялись у студентов, различающихся по определенному ряду объективных и субъективных параметров.

Формирующий этап эксперимента предусматривал изучение особенностей изменения представлений студентов о супружеской ревности в условиях специально организованного обучающего и развивающего воздействия на них. Для развития представлений студентов о ревности было организовано специальное воздействие, сочетающее обучающий и развивающий эффекты.

В проведенном исследовании получены результаты, позволившие сделать следующие выводы.

1. Представления студентов о ревности являются субъективным выражением их осведомленности о сущности ревности, основаниях ее возникновения, состоянии и перспективах развития супружеских отношений, проникнутых чувством ревности. 
2. Представления студентов о супружеской ревности полидетерминируются объективными и субъективными факторами. К объективным факторам развития представлений студентов о супружеской ревности относятся половая принадлежность, опыт супружеской жизни и опыт наблюдения ревности в отношениях родителей. К субъективным факторам развития представлений студентов о супружеской ревности относятся особенности их эмоциональной и ценностной сфер личности.

3. Развитие представлений студентов о супружеской ревности характеризуется расширением их осведомленности о причинах и последствиях возникновения ревности в отношениях супругов и укреплением причинно-следственных связей между данными структурными компонентами. По состоянию сформированности представлений о супружеской ревности студенты вуза могут быть дифференцированы на три группы: студенты со сформированными, диффузными и иллюзорными представлениями о ревности.

4. Студенты вне зависимости от состояния сформированности их представлений о ревности с большей или меньшей конкретностью отмечают, что ревность всегда сопровождается определенными нарушениями коммуникативной сферы супругов: возникает личностная тревожность, снижается уровень взаимного доверия, появляются конфликты. Выяснение отношений между супругов протекает с высоким уровнем конфликтности и агрессивности. Неумение привлечь продуктивные стратегии поведения в конфликте приводит к их затягиванию и окончательному разрушению супружеских отношений.

5. Формирование представлений студентов вуза о ревности дает позитивные результаты в сфере их супружеских отношений, если основываться на расширении у них информированности о психологии семейной жизни и межличностных отношений в сочетании с развитием качеств, способствующих построению гармоничных супружеских отношений.

6. Формирование представлений студентов о супружеской ревности на основе специально разработанной комплексной программе, предусматривающей теоретические и практические аспекты построения супружеских отношений, снижает вероятность возникновения проявлений ревности в реальной жизни студентов.

Подводя итоги нашего исследования, отметим, что оно представляет собой только один из возможных вариантов изучения широкого поля проблематики ревности, в целом, и супружеской ревности, в частности. Выбранный нами ракурс обращения к субъективному отражению супружеской ревности в представлениях студентов позволил получить психологические данные о том, каким образом ревность формируется к начальному периоду молодости человека, когда он только обретает самостоятельность и получает возможность выстраивать свои супружеские отношения. Очевидно, что работа в данном направлении может быть продолжена с использованием других исследовательских ракурсов, с привлечением других исследовательских методов и методик, другой исследовательской выборки и т.д. 
Вместе с тем, отметим, что результаты, представленные в нашей работе, могут выступать в качестве исходной теоретико-эмпирической базы для проведения дальнейших исследований в направлении изучения психологических особенностей супружеской ревности. Немалую ценность в этой связи представляет разработанная нами частная методика семантического дифференциала, направленная на выявление психологической структуры представлений о ревности.

1.

\section{Литература}

2.

3. 